\title{
The Maintenance of National Culture Security in the Circumstance of Soft Power Competition
}

\author{
Zhihong Meng ${ }^{1}$ \\ ${ }^{1}$ College of Politics, Sichuan Agricultural University, Ya'an, China \\ Correspondence: Zhihong Meng, College of Politics, Sichuan Agricultural University, 46, Xinkang Road, \\ Yucheng District, Ya'an, China. Tel: 86-1-355-158-2808. E-mail: mengzhihong78@163.com
}

Received: June 29, 2012 Accepted: July 19, 2012 Online Published: August 21, 2012

doi:10.5539/jpl.v5n3p93 URL: http://dx.doi.org/10.5539/jpl.v5n3p93

This research is financed by the "Two-Support Program" of Sichuan Agricultural University.

\begin{abstract}
Presently, the competition of soft power has become an important trend in international competition. The expansion and dissemination of culture soft power has even caused challenges and risks to other countries' national security. Therefore, by summarizing the characteristics of and the trends of international culture soft power competition, considering the chief impacts on Chinese culture security, to identify the solutions is an important content of the protection for culture security.
\end{abstract}

Keywords: culture, soft power, national security

\section{Introduction}

The proposal of the "soft power" concept by Joseph Nye has provided a clearer theoretical perspective for scholars inside and outside studying the international competition and cooperation in times of globalization. In international communication, except the traditional exchange of materials, the dissemination and expansion of cultures, ideologies, and values has unconsciously influenced and changed people's thoughts and recognitions and transformed their behavioral patterns, realizing the objectives and values of disseminators. Along with the expansion of reform and opening up and the increase of international exchange, China has also faced challenges of culture security, caused by the soft power of powerful countries. Therefore, it is necessary to research and analyze the protection for national culture security under the background of soft power competition.

\section{The Characteristics and Trends of Culture Soft Power Competition}

Among all the components of soft power, the culture is the essential one. The competition of culture soft power tends to be fiercer.

\subsection{Improve Culture Development to the Point Of National Strategy}

The trend of globalization makes all countries realize that an international giant country is not only based on the growth of economic power or the increase of GDP. Therefore, with the pursuit for material wealth, major countries in the world begin to understand the culture at the level of national strategy. Early during the period of World War II, the United States has improved the culture and education- related business to the national level, using the state and government to convey its life style, values, ideology, politics, and economic system by "culture diplomacy". Although the culture policy in the United States is featured by uncertainty and discontinuity, the culture strategy of developing influential culture industry and exporting cultural products and values has never changed (Xianchao Deng, 2009). In the $20^{\text {th }}$ century, France, with rich cultural heritages, has begun to more directly intervene in foreign cultural affairs. It absorbed many non-government cultural organizations into its foreign strategy. The Ministry of Foreign Affairs changed the mission of the Department of French Writing into the knowledge expansion of French in 1920 (Shuyi Peng, 2009). Japanese government develops cultural diplomacy actively and takes the dissemination of national culture, the absorption of excellent foreign cultures, and the generation of new culture styles in communication as the three ideas and spiritual backbone of culture diplomacy (Zhong Huang \& Xiaosong Tang, 2011). 


\subsection{Use the Hard Power to Support the Expansion of Culture Soft Power}

The distinctive feature of hard power is mandatory, while the soft power tends to achieve objectives by attraction and appeal. In practice, the two are usually interactive. On one hand, hart power gives the culture soft power the material support for its realization and expansion. For example, the United States' cultural attraction, displayed in books, movies, TVs, and Internet and its capability of drawing more than 100 countries and regions to join in The Fulbright Program are closely associated with its great progresses in economic power, political dominance, scientific and technological innovation, education and scientific research. On the other hand, the development of hard power provides powerful and wider communication means and media for the realization of the culture soft power. In times of information, the fast development of science and technology, especially the satellite and the Internet, provides extremely convenient conditions for the realization and expansion of the culture soft power. Especially in the field of Internet, some countries grasp the top position in the expansion of the culture soft power by technological advantages and information systems, making other countries fall into negative positions in the communication of culture and information (Zilin Zhao, 2011). What's more, Hillary mentioned in the speech in George Washington University that the U.S. government would support the freedom of online talking, assembly, and association, and continue to provide technologies for people who suffered from a government-imposed Internet bypassing the network check. In a sense, it pushes the competition of the culture soft power to a new level.

\subsection{Use Modern Industrial and Technological Communication to Achieve the Realization of the Culture Soft Power}

To transform one country's cultural resources into actual culture soft power needs certain media, materials, and means. In this field, developed countries have sufficiently operated and disseminate their cultural resources by advanced cultural industries and modern science and technologies, conveying their values and ideologies by movies, books, Internet, and other means quietly. Today, the United States has more than 1500 daily papers, about 8000 weekly papers, 12,200 journals, 1,965 radio stations, 1440 TV stations, three TV giants (ABC, CBC, and NBC), and the most influential movie production base in Hollywood (Jun Wang). Besides, the United States continues to absorb more talents in the field of cultural industry by its economic, scientific and technological powers, and industrial environment, promoting the creativity and the development of cultural industry.

\section{The Impacts of the Competition of the Culture Soft Power on Chinese Culture Security}

In the globalization era, culture has become an important component of national comprehensive power. The comprehensive security view substitutes the one-aspect security view. The competition of soft power, along with the process of globalization, proposes challenges for the national culture security. Under the condition of western developed countries holding the leading place in the field of culture, Chinese culture security suffers from threats outside.

\subsection{Threaten the Security of National Ideology}

Ideology is the core of the security of national culture. Presently the impacts of the culture soft power present certain challenges to Chinese ideology security, especially the guiding position of Marxism. In the era of culture globalization, capitalist countries strengthen the dissemination and the penetration of ideology to socialist countries, continuously promoting the western democracy, freedom, and human rights, advertising the political system, and life style, and criticizing the achievements and significance of socialist construction, with the hope of ruining the guiding status of Marxism in China's construction and development. Make the faith in Marxism tend to decline by generations and time in China today. Some people with weak wills even face faith crisis (Fengyan Jiang \& Shuxia Wu, 2011).

\subsection{Affect People's Values and Morals}

The globalization tide and China's market economy reform cause the import of secular ideology, e.g. the materialism, consumerism, and money worship, into China. In the background of material worship, the original values and ideologies of Chinese suffer from impacts, resulting in a landslide of social moralities. Moral anomie happens a lot. The concept of honor, the right and wrong is distorted. "The global expansion of mass culture, with the core of consumerism and characterized by interests and entertainment, changes the world quietly. Particularly, it occupies the brains and minds of the youth and forms great impacts on other countries' national cultures. Here, western countries are also the victims. So does China, when China is busy in joining the process of globalization (Fengyan Jiang \& Shuxia Wu, 2011). 


\subsection{Challenge the Traditional Culture of China}

Although Joseph Nye has defined the concept of "soft power" (Joseph Nye, 2005), traditional culture is the spirits and powers accumulated by Chinese in production and living in thousands of years, which is capable of integrating and unifying national members, being the main source of China's culture soft power. However, in the turmoil of culture globalization, Chinese traditional culture suffers great challenges. On one hand, since the reform and opening up, along with the significant input of western countries' cultural products and material goods, the western values and life attitudes have spread among the public. China's traditional culture, taking kindness, loyalty, manners, wisdom, and credit as the core, has been ruined to certain degree. The material worship, morality absence, and spiritual emptiness have appeared. Once traditional culture loses its independence and subjectivity, it will lose the basis for self survival in the intense competition of soft power. On the other hand, China's traditional culture with profound meanings is supposed to be the culture resources for China building its culture soft power. On the contrary, it has been explored and used by other countries. Hollywood took advantages of China's traditional culture resources and produced popular movies, e.g. Mulan, and Kung Fu Panda. By this way, Chinese traditional culture resources have been transformed into the media conveying the U.S. values.

\subsection{Affect the Development of Culture Industry}

Similar to global economic competition, developed western countries have the absolute advantages in the competition of culture globalization. By virtue of these advantages, the developed countries control and monopoly the culture market in the world, invading other countries' culture industry. Although China has rich and colorful traditional culture, the degree of modernization for the development of culture industry is far from satisfying. Take the foreign trade of Chinese culture for example. "For many years, the ratio of imported books to the exported is about 10:1, and the ratio even reaches 100:1 above between China and European countries and the United States. There is serious trade deficit. From the year 2000 to 2004, China imports 4332 movies and half are from the United States. Only few Chinese movies are exported. In more than 3000 universities of the United States, about 800 of them provide the course of Chinese language. However in China, the primary schools, or even the pre-school teach students English language (Anlu Xiao, 2007).

\section{Strengthen China's Culture Soft Power and Protect the Security of National Culture}

The Sixth Plenary Session of the 17th Central Committee of the Communist Party (CCP) of China clearly pointed out that under the background of world polarization and deepening economic globalization, the communication between different thoughts and cultures should be more frequent. Culture makes itself prominent for its status and effects in the competition of comprehensive national power. The mission of protecting national culture security becomes tougher, and the needs for enhancing China's culture soft power and international influences are more urgent (People's Daily).

\subsection{Promote the Process of Marxism Popularization}

In recent years, China established the Confucius Institute and produced the video of "Image of China" in order to make foreign countries recognize and understand China correctly. However, if China hopes to improve the strengths of culture soft power, it must dig out the special culture resource - Marxism, displaying the charm and attraction of China's culture soft power in the process of Marxism popularization.

Although Marxism is the guiding thought of the proletarian revolution and construction, with the character of distinct ideology, its ultimate pursuit contains the common values and goals of human being. First of all, Marxism is the scientific statement of the law of human social development. The two historical achievements, namely the Mao Zedong Thought and the socialism theoretical system with Chinese characteristics, formed by the $\mathrm{CPC}$ in the process of localization of Marxism in China have been verified by directing and guiding Chinese revolution and construction. Therefore, to promote the popularization of Marxism in China can enhance the appeal of Marxism, make the public insist on political agreement, form the cohesion of state and nation, and establish sound basis for national culture security. Secondly, only by drive the process of the popularization of Marxism, can it make China occupy the invincible position in the global culture competition. Chinese practices fully prove that the socialism is right for China's conditions and needs. Socialism has already help China achieve significant accomplishments, which will undoubtedly deserve to be learned by other countries, forming the culture attraction.

\subsection{Improve the Chinese Mode}

The formation of culture soft power should not just depend on the propaganda and dissemination in foreign countries. It should be supported by strong hard power. From perspective of hard power, the most attractive part 
is the speed and scale of China pursuing the cause of socialism construction. Under the leadership of CPC, China has become a world giant with relatively stronger economic powers from a poor country, building a well-known "Chinese mode", which should be the special material support for China's soft power (Honghua Men, 2007). Therefore, in the process of exchanging with foreign countries, the Government should strengthen the publicity on the achievements of China's reform and opening up and modernization construction, displaying the superiority of the socialist system by comparisons, and enhancing the impacts and attractions of socialist economy, politics, and culture system.

\subsection{Promote the Dissemination of Core Values}

Although the culture soft power is mainly reflected its impacts on others, by generating a kind of attraction and allure over other countries in a quiet way (Joseph Nye), the fundamental precondition for the generation of influences is the formation of powerful cohesion and recognition in its own nationals. These nationals can emit attraction unconsciously in foreign exchanges (Yuan Han, 2004). Therefore, we should vigorously strengthen the construction and dissemination of socialist core values. The core values are the dominant values and judgments in one country and society, and the external show of national spirits, recognized and followed by all nationals. In the construction of the culture soft power, we should emphasize on directing the construction by the theories of Marxism localization in China, integrating the nationals' recognitions by China-featured socialism common wills, stimulating the enthusiasm for developing Chinese culture by national spirits with patriotism and modern spirits in times of reform and opening up, and guiding the evolvement of national morality by the socialist concept of honor and shame. Only by this way, can we resist the penetration and erosion of western social values in the fierce competition of ideology, protecting the improvement of the culture soft power.

\subsection{Develop China's Excellent Traditional Culture}

Chinese civilization, formed in thousands of years, is not only the inexhaustible force for Chinese unifying together and fighting hard, but also the important source for China's culture soft power. Besides, it has important guiding values for world civilization and development (Yihe Pan, 2007). Therefore, in the fierce competition of culture globalization, we must strive for developing and digging out the excellent culture sources in Chinese traditions. Popularize the harmony ideas, e.g. "kind governance", and "combination of God and people", in traditional culture based on actual social development. Attract foreign people to understand Chinese language and the deep meanings of Chinese culture by national powers. Introduce and disseminate Chinese civilization by establishing the Confucius Institute. Develop the culture diplomacy vigorously.

\subsection{Strengthen the Construction of Culture Industry}

The culture industry can provide material basis and communication media for the formation of culture soft power in one country. Therefore, in order to protect the national culture security, China must strengthen the construction of culture industry. First of all, promote the innovation of culture management system and support the growth of culture enterprises by policies. Follow the primary laws of market competition, make the culture exert its unique charm, and promote the formation and development of culture industry (Siqu $\mathrm{Li}, 2007$ ). Secondly, implement the "going-out" strategy of culture. Use culture industry, culture exchange, and culture diplomacy as carriers, form the trend of progressive development of culture, and build the positive image of China as a giant culture country.

\section{References}

CPC Central Committee. (2011). The CPC Central Committee's decision on deepening the cultural system reform and promoting the great development and prosperity of socialism culture. People's Daily, 26 (1).

Deng, Xianchao. (2009). The Enhancement about cultural soft power of developed country and its enlightenments. Theoretical Exploration, 2, 35.

Han, Yuan. (2004). Comments on the situations of China's national culture security. Contemporary World \& Socialism, 4, 106.

Huang, Zhong, \& Tang, Xiaosong. (2011). Analysis if Japan's non-national diplomacy. Japan Studies, 1, 60.

Jiang, Fengyan, \& Wu, Shuxia. (2011). The crisis of Chinese culture security in times of globalization. People's Tribune, 14, 207.

Joseph, S. Nye Jr. (2005). The rise of China's soft power. The Wall Street Journal Asia, December 29.

Li, Siqu. (2007). Review of Cultural Industry. Hangzhou: Zhejiang University Press.

Men, Honghua. (2007). Assessment report on the soft power of China. International Review, 2, 19. 
Joseph S. Nye Jr. The Benefits of Soft Power [EB/OL].http://hbswk.hbs.edu/archive/4290.html.

Pan, Yihe. (2007). Culture Security. Hangzhou: Zhejiang University Press.

Peng ,Shuyi. (2009). A discussion of French cultural diplomacy. European Research, 4, 109.

Wang, Jun. (2011). On America's cultural industry . Retrieved from http://news.xinhuanet.com/world/2011-11/08/c_111153906.htm

Xiao, Anlu. (2007). The import of oversea cultural products and the security of Chinese culture. Gansu Theory Research, 1, 25.

Zhao, Zilin. (2011). An exploration on the culture security of China under the economic globalization. Journal of Ideological \& Theoretical Education, 8, 71. 